УДК: 004.89:519.876

Цідило Іван Миколайович, кандидат педагогічних наук, доцент кафедри комп’ютерних технологій, докторант Тернопільського національного педагогічного університету імені Володимира Гнатюка, м. Тернопіль, tsidylo@ukr.net

\title{
НЕЧІТКІСТЬ ТА НЕВИЗНАЧЕНІСТЬ: ОПИС, ВИМІРЮВАННЯ І СПОСОБИ ВИРІШЕННЯ В МОДЕЛЮВАННІ ПЕДАГОГІЧНИХ ЯВИЩ
}

\begin{abstract}
Анотація
Розглядається проблема представлення знань в дослідженні педагогічних явищ. Наведені схеми представлення неясності або невизначеності, наведена класифікація їх основних властивостей. Відзначено, що для деяких класів є підхід, орієнтований на теорії нечітких множин та штучному інтелекті. Що стосується завдання фактичного вимірювання різноманітних характеристик педагогічного явища, запропоновано застосування експертних систем, які побудовані на нечіткій базі знань предметної області. Підведено підсумки про переваги i недоліки розглянутих технологій експертних систем, що розроблені на основі: правил, моделей, досвіду та гібридних систем.

Ключові слова: невизначеність, нечіткість, випадковість, неточність, штучний інтелект, експертні системи.

Постановка проблеми в загальному вигляді. Будь-якому вимірюванні певних характеристик педагогічного явища повинне передувати глибоке якісне його вивчення. Як зазначається в роботі [7, с. 12] уже на цьому етапі вивчення педагогічного явища ми приходимо до його спрощення шляхом висунення на перший план лише деяких основних характеристик, подальше спрощення, схематизація яких дозволяє перейти до кількісного опису явища, що дає можливість використовувати відповідні математичні методи і засоби. Проте, не розглядаючи одні характеристики педагогічного явища, спрощуючи інші, ми, безперечно, втрачаємо про нього частину інформації. Уже на етапі уточнення якісної моделі педагогічного явища постає проблема вимірювання різноманітних його властивостей.
\end{abstract}


«За своєю природою оцінка є наближенням. Часто достатня досить наближена характеристика набору даних, оскільки в більшості завдань, що їх вирішує людина, не вимагають високої точності. Людський мозок використовує допустимість такої неточності, кодуючи інформацію, що «достатня для завдання» (чи «достатню для вирішення») елементами нечітких множин, які лише наближено описують вхідні дані» $[3$, с. 8].

Існує тенденція відкидати такі терміни, як неясність, невизначеність, нечіткість і неточність через їх ненаукову або ірраціональну концепції. Проте у реальному світі ми неминуче стикаємося з багатьма випадками, коли неможливо уникнути проблеми обліку незрозумілої або неточної інформації про відомості, явища або події і т. п. Така ситуація існувала до 1965 р., коли Л. Заде запропонував теорію нечітких множин — багатообіцяючу теорію і техніку для аналізу та представлення незрозумілих або неточних понять, що використовуються в твердженнях про події і факти для опису відношень між об'єктами або діями.

Сучасна бібліографія з теорії нечітких множин охоплює не лише теоретичні аспекти теорії, але і прикладні області. Зокрема, застосування теорії нечітких множин, мабуть, особливо доречно швидше в так званих гуманітарних науках, таких як лінгвістика, психологія, логіка, громадські науки, управління наукою і т. п., ніж в галузі техніки, оскільки в гуманітарних науках доводиться частіше стикатися 3 суб’ єктивними даними. Потрібно сказати, що теорія нечітких множин виражається передусім в систематичному, але не обов’язково завжди кількісному методі обробки нечітких даних. Для нас є цікавою можливість опису саме педагогічних явищ.

Аналіз останніх досліджень та публікацій. Питання моделювання та основ теорії вимірювань 3 описом інструментарію наукового пошуку закономірностей педагогічного процесу обгрунтовано в працях П. М. Воловик, М.І.Грабарь, К. А. Краснянської, В. І. Міхеєва та ін. Основоположником теорії нечітких множин вважається професор Каліфорнійського університету (Берклі) Лотфі А. Заде (Lotfi A. Zadeh). Його робота «Fuzzy Sets», що з’явилася в 1965р. в журналі Information and Control, №8, заклала основи моделювання інтелектуальної діяльності людини. Експериментальне застосування теорії нечітких множин починається з 1975 р., коли Мамдані та Ассіліан (Mamdani and Assilian) побудували перший нечіткий контролер для управління простим паровим двигуном. Значний вклад у розвиток теорії i 
практики експертних оцінок внесли українські вчені: В. М. Глушков, Г. М. Гнатієнко, Н. 3. Шор та ін. Наступне практичне застосування даної теорії відобразилось у побудові нечітких експертних систем, що висвітлено в працях Д.Ф. Люгера, С. Д. Штовби та ін. Проте, праці, у яких висвітлено застосування інтелектуальних технологій у вивченні педагогічних явищ, нам не зустрічались. Саме бази знань, що сформовані експертами відповідно особливостям предметної галузі, на нашу думку, забезпечують успіх у побудові ефективної нечіткої експертної системи.

Метою статті $\epsilon$ аналіз нечіткості та невизначеності з можливістю подальшого практичного застосування їх у процесі розробки експертних систем моделювання педагогічних явищ.

Виклад основного матеріалу. Теорія нечітких множин дала схему розв’язання проблем, у яких суб'єктивне судження або оцінка відіграють центральну і значну роль у процесі трактування чинників неясності або невизначеності. Ніхто не заперечуватиме того факту, що слід уміти розпізнавати такі нечіткі множини, як сукупність високих людей або множину великих чисел «як таких». Проте критики стверджують, що теорія нечітких множин не пропонує раціонального або емпіричного методу визначення значення функції належності i, крім того, що немає достатньої ясності відносного того, як проявляється індивідуальність або суб' єктивність людини у визначенні значення степеня належності. Більше того, деякі 3 них говорять, що нечітку логіку можна підвести під категорію так званого логічного позитивізму, оскільки майже всі нечіткі логічні оператори можна вивести 3 відношення більше-менше, визначеного на множині значень даних функцій належності. Підсумовуючи наведені критичні зауваження, автор [8] говорить, що теорія нечітких множин ніби охоплює основну проблему, що вона розвивається шляхом логічного позитивізму і не містить філософського і теоретико-пізнавального аналізу понять неоднозначності і невизначеності. Добре відомо, що поняття випадковості також є деяким типом представлення невизначених явищ або часто спостережуваних подій. Теоретико-імовірнісне поняття випадковості вже давно віднесене до категорії об'єктивних понять і розглядається як додаткове до поняття причинності; таке представлення підкріплюється концепцією відтворюваних експериментів, яка узгоджується із спостереженнями в галузі природних наук і в техніці. Можливо, і до суб'єктивної ймовірності можна відноситися як до шкали 
неоднозначності. Подібно до об'єктивної ймовірності — найпопулярнішої i поширенішої з концепцій невизначеності - суб'єктивна ймовірність задовольняє аксіомі імовірнісної міри і виявляється позитивною і відтворюваною [10]. Проте широкий розгляд різноманітності неясних, невизначених і неточних явищ, подій або фактів, а також зв'язків між об’єктами і операціями, показує, що існують різні класи неясності або невизначеності, які не завжди будуть пов'язані з випадковістю або нечіткістю, як наведено в роботі [8, с. 39] та показано в табл. 1. Зокрема автор стверджує, що для розгляду деяких класів неясності і невизначеності можуть виявитися корисними й ефективними такі абсолютно різні підходи, як теорія штучного інтелекту та методи теорії пізнання.

Табличя 1

Методології класів неясності або невизначеності

\begin{tabular}{|c|c|c|}
\hline Клас неясності & $\begin{array}{c}\text { Використовувана } \\
\text { методологія }\end{array}$ & $\begin{array}{c}\text { Наукові дисципліни, що } \\
\text { лежать в основі } \\
\text { методології }\end{array}$ \\
\hline $\begin{array}{l}\text { А. Невизначеність, } \\
\text { випадковість: } \\
\text { а) події і (чи) стан } \\
\text { середовища, обумовлені } \\
\text { випадковістю; }\end{array}$ & $\begin{array}{l}\text { Теорія стохастичних } \\
\text { процесів і теорія } \\
\text { ухвалення рішень, міра } \\
\text { ентропії }\end{array}$ & Теорія ймовірності \\
\hline $\begin{array}{l}\text { б) явища, що не піддаються } \\
\text { аналізу і вимірюванню із } \\
\text { скільки завгодно великою } \\
\text { точністю }\end{array}$ & Принцип невизначеності & Квантова механіка \\
\hline $\begin{array}{l}\text { Б. Нечіткість: } \\
\text { а) нечіткість як наслідок } \\
\text { суб'єктивності або } \\
\text { індивідуальності людини } \\
\text { б) нечіткість або неясність в } \\
\text { процесах мислення і } \\
\text { висновку: }\end{array}$ & $\begin{array}{l}\text { Теорія нечітких множин, } \\
\text { теорія суб' єктивної } \\
\text { ймовірності }\end{array}$ & $\begin{array}{l}\text { Безкінечно-значеннєва } \\
\text { логіка Лукасевича }\end{array}$ \\
\hline $\begin{array}{l}\text { 1) нечітке або неточне } \\
\text { заключення; }\end{array}$ & $\begin{array}{l}\text { Теорія нечіткого або } \\
\text { наближеного міркування }\end{array}$ & $\begin{array}{l}\text { Нечітка логіка (логіка } 3 \\
\text { лінгвістичними } \\
\text { значеннями істинності, } \\
\text { пропозиційне числення, } \\
\text { числення предикатів) }\end{array}$ \\
\hline $\begin{array}{l}\text { 2) неясність внаслідок } \\
\text { складності і (чи) } \\
\text { різноманіття виводів }\end{array}$ & $\begin{array}{l}\text { Звернення до підходу, що } \\
\text { моделює процес пізнання }\end{array}$ & $\begin{array}{l}\text { Методи штучного } \\
\text { інтелекту, підкріплені } \\
\text { теорією пізнання }\end{array}$ \\
\hline $\begin{array}{l}\text { В. Нечіткість або неясність, } \\
\text { супутня природним мовам: }\end{array}$ & $\begin{array}{l}\text { Теорія нечітких множин, } \\
\text { нечітка логіка, модальна } \\
\text { логіка }\end{array}$ & \\
\hline
\end{tabular}


a) нечіткість опису або представлення;

б) неясність, пов'язана із складністю і (чи) різноманіттям семантик $\mathrm{i}$ структур природних мов Д. Розпливчатість або смутність малюнків, картин або сцен:

a) розпливчатість малюнків і картин

б) Неясність, що виникає в процесі інтерпретації малюнків і картин Е. Неясність внаслідок структурної складності і (чи) різноманіття інформації
Теорія нечітких множин, нечітка логіка, модальна логіка

Семантика інформації

Техніка фільтрації.

Релаксаційна операція

Техніка інтерпретації образів

Техніка структурного моделювання
Техніка представлення знань, підкріплена теорією штучного інтелекту

Теорія стохастичних процесів.

Ітеровані повторні операції А. Розенфельда Техніка представлення знань, методи штучного інтелекту

Методи нечіткого структурного моделювання DELFI, PATTERN, ISM, DEMATEL, KY, FSM (метод нечіткого структурного моделювання), нечіткий метод PATTERN

У 1972 р. Л. Заде запропонував теоретико-множинну інтерпретацію лінгвістичних змінних i обмежень [11], яка відбивала лінгвістичні аспекти відношення належності в нечітких множинах. Наприклад, якщо висловлювання про деякий факт несе відтінок невпевненості, то його можна характеризувати лінгвістично як, скажімо, істинне не істинне, дуже істинне, більш-менш істинне, не дуже істинне і т. п., визначаючи кожним таким істинно-значимим представленням нечіткого об'єкта сенс лінгвістичного обмеження. Розглядаючи обмеження $h$ як оператор, що застосовується до терма 3 певним значенням, Л. Заде запропонував метод розрахунку значення складеного терма виду $x=h u$, що представляє лінгвістичну змінну.

Дещо пізніше [4] Л. Заде ввів до розгляду нечітку логіку з лінгвістичними, а не числовими значеннями істинності. Згідно з такою логікою висловлювання може набувати істиннісного значення типу: істинно, неправдиво, абсолютно істинно, зовсім неправдиво i т. п. - i кожне таке значення представляє нечітку підмножину 
одиничного інтервалу. Звідси відбувається назва лінгвістичної логіки як логіки 3 лінгвістичними значеннями істинності на противагу логіці з числовими значеннями істинності, теорії нечітких множин, що також розглядається у рамках.

Неясність, невизначеність або неточність, що знаходяться в смислових значеннях або виводах, властиві природним мовам 3 надзвичайно складними структурами і різноманітними поняттями або ті, що проявляються при інтерпретації сенсу малюнків, картин і сцен - це типові приклади категорій, операція з якими за допомогою однієї тільки теорії нечітких множин або нечіткої логіки недостатньо для правильного відображення розумової роботи людини [8]. Для розуміння навіть, здавалося б, простих речей людина залучає різноманітну надмірну інформацію. Іншими словами, людина використовує не лише великі знання про структуру природних мов, але також і умови, у яких сталися події або явища, враховує умови, за яких зроблено висловлювання. Для того щоб співвіднести 3 обчислювальною системою такі види розумової діяльності людини, як міркування і розуміння, треба розв’язати такі завдання: 1. Треба уміти добре представляти за допомогою абстрактних моделей, що відбивають семантику об' єкта, знання і здібності людини до рішення завдань. 2. Семантика має бути описана за допомогою добре певного синтаксису. 3. На противагу абстракції семантика має бути реалістичною i прагматичною, щоб з іï допомогою можна було впоратися з конкретною ситуацією у реальному світі, у якому для розв’язання реальних проблем потрібні конкретні, індивідуальні і специфічні знання [8, с. 46]. А це вже, на нашу думку, не що інше як інженерія знань, яка забезпечує плідний підхід до проблем, що розв'язуються на основі знань, і в процесі якого використовуються експертиза й евристика, як і методи символічного виведення і представлення інформації, про які говорять, що вони $\epsilon$ принципами і методами штучного інтелекту.

Що стосується завдання фактичного вимірювання різноманітних характеристик педагогічного явища, то це завдання можна віднести також до невизначених, так як «... в навчально-виховному процесі ми виділяємо як педагога, так і учня, які можуть описуватись великим набором властивостей. При цьому кожна властивість може стати суттєвою в процесі опису того чи іншого педагогічного явища» [7, с. 14].

У роботі [7, с. 11] автор виділяє два основних підходи до моделювання педагогічного явища. Перший підхід базується на необхідності грубої схематизації i 
спрощенні самого явища, що дозволяє описувати окремі характеристики його прояву на строго кількісному рівні з використанням різноманітних методів багатомірного статистичного аналізу. Другий підхід до моделювання педагогічного явища - шлях строгого, формального їх опису, що заснований на застосуванні алгоритмічних моделей. Перевага другого підходу, за словами В. І. Міхеєва, полягає в тому, що в поєднанні 3 обчислювальною технікою з'являються можливості практичної формалізації й опису педагогічного явища у багатьох його суттєвих проявах i особливостях. Виходячи 3 обговорюваних проблем, доцільним вважається застосування третього підходу для моделювання педагогічного явища - експертні системи, що побудовані на нечіткій базі знань предметної галузі.

Людина-експерт здатна діяти на високому рівні, оскільки багато знає про сферу своєї діяльності. Це просте спостереження є головним обгрунтуванням для розробки експертних систем, заснованих на знаннях. Експертні системи використовують знання специфічної предметної галузі. Зазвичай, розробники експертної системи отримують ці знання за допомогою експертів, методологію і діяльність яких потім емулює система. Так само, як досвідчені люди, експертні системи $є$ «фахівцями» 3 вузького кола проблем. Подібно до людей, вони мають як теоретичні, так і практичні знання: людина-експерт, що забезпечує систему знаннями, зазвичай, привносить власне теоретичне розуміння предметної галузі, а також забезпечує систему «хитрощами», найкоротшими шляхами рішення й евристиками, отриманими 3 досвіду рішення проблем [5, с. 273].

Експертні системи, зазвичай, надають такі можливості.

- Відстежують свої процеси міркування, виводячи проміжні результати і відповідаючи на питання про процес рішення.

- Дозволяють дещо модифікувати базу знань (додавати i видаляти інформацію).

- Міркують евристично, використовуючи для отримання корисних рішень багато в чому недосконалі знання.

У роботі [5, с. 274] наведено загальні завдання експертних систем.

- Інтерпретація - формування високорівневих виводів 3 наборів рядків даних.

- Прогнозування - проектування можливих наслідків цієї ситуації. 
- Діагностика - визначення причин несправностей у складних ситуаціях на основі спостережуваних явищ.

- Проектування - знаходження конфігурації компонентів системи, яка задовольняє цільовим умовам і безлічі проектних обмежень.

- Планування - розробка послідовності дій для досягнення безлічі цілей за цих початкових умов і тимчасових обмежень.

- Моніторинг - порівняння спостережуваної поведінки системи 3 іï очікуваною поведінкою.

- Інструктування - допомога в освітньому процесі 3 вивчення технічної галузі.

- Управління - управління поведінкою складного середовища.

Успіхи побудови експертних систем для розв'язання складних практичних проблем продемонстрували працездатність основної ідеї побудови систем на базі знань. Ефективність механізму міркування визначається знаннями експерта в даній галузі, а не методами міркування. Це спостереження піднімає один із головних питань штучного інтелекту - питання представлення знань. На практичному рівні кожен інженер із знань має вибрати найефективніший спосіб їх представлення. Представлення знань пов'язано також із переліком таких теоретично важливих i інтелектуально складних питань, як управління неповною та невизначеною інформацією, визначення виразності представлення, відношення між мовою представленням і навчанням, отриманням знань й ефективністю механізму міркування.

У роботі [5] розглянуто декілька технологій експертних систем, зокрема експертні системи, що розроблені: на правилах, на основі моделей, на основі досвіду та гібридні системи. Також підведені підсумки про переваги і недоліки кожного 3 перерахованих підходів до розв’язання проблеми.

Міркування на основі правил. Переваги цього підходу зводяться до такого.

1. Можливість використовувати знання експертів в досить простій формі. Це важливо в галузях, що залежать від евристик управління складною i/або відсутньою інформацією.

2. Правила відображаються в простір стану пошуку. Можливості пояснення полегшують налаштування програм. 
3. Виділення знань від управління спрощує розробку експертної системи, забезпечуючи ітеративний процес розробки, у якому інженер накопичує, реалізує i тестує окремі правила.

4. В обмежених предметних галузях можливі хороші результати. Оскільки для інтелектуального розв’язання завдання необхідний великий обсяг знань, експертні системи обмежуються вузькими областями. Проте існує багато галузей, у яких розробка подібних систем виявилась надзвичайно корисною.

5. Хороші можливості пояснення. Хоча системи на основі правил підтримують гнучкі, проблемно-залежні пояснення, необхідно відзначити, що максимальна якість цих пояснень залежить від структури і змісту правил. Можливості пояснень в системах, що засновані на даних і на меті, дуже відрізняються.

Недоліки міркувань заснованих на таких правилах.

1.Правила, що отримані від експертів, часто є евристичними за природою і не охоплюють функціональних знань чи знань, що засновані на моделях.

2.Евристичні правила, зазвичай, не є робастними і не дозволяють керувати відсутньою інформацією чи неочікуваними значеннями даних.

3.Іншою особливістю правил є незастосовуваність на межі галузі визначення. На відміну від людей, системи на основі правил у разі зіткнення з новими проблемами, зазвичай, не здатні повертатись назад до першопочаткових принципів міркування.

4.Застосування пояснень лише на описовому рівні. Теоретичні обгрунтування відсутні. Це пов'язано з тим, що евристичні правила напряму пов'язують вхідні дані 3 рішеннями та не забезпечують більш глибоких міркувань.

5.Знання є проблемно-залежними. Формалізовані знання про деяку предметну галузь, як правило, дуже специфічні та можливе застосування тільки до даної галузі. Сучасні мови представлення знань не забезпечують гнучкості, властивій людині.

Міркування на основі досвіду. Переваги міркувань на основі досвіду.

1. Можливість напряму використовувати історичний досвід. У багатьох галузях необхідну інформацію можна отримати 3 наявних історичних матеріалів, записів чи інших джерел. Водночас відкидається необхідність інтенсивного отримання знань за допомогою людини-експерта. 
2. Можливість скорочення міркувань. Якщо відомий аналогічний випадок, нові завдання розв'язуються набагато швидше, ніж у разі використання правил чи моделей.

3. Міркування на основі досвіду дозволяють уникнути попередніх помилок i використовувати минулі успіхи. Вони забезпечують модель навчання, як цікаву 3 теоретичної точки зору, так і достатньо практичну для застосування в складних ситуаціях.

4. Не вимагається усестороннього аналізу знань про дану галузь. На відміну від систем, що засновані на правилах, де інженер із знань має описувати взаємодію правил, міркування на основі досвіду забезпечують просту адитивну модель отримання знань. Для використання цього підходу необхідно забезпечити відповідне представлення випадків, індексування даних і стратегію адаптації.

5. Відповідні стратегії індексування підвищують ефективність вирішення завдань. Потужність механізму міркувань на основі досвіду визначається можливістю виявляти відмінні особливості цільової проблеми та вибирати відповідний випадок із бази даних. Алгоритми індексації часто забезпечують цю функціональність автоматично.

Недоліки міркувань на основі досвіду.

1. Опис випадків, зазвичай, не враховує більш глибокі знання про предметну галузь. Це знижує якість пояснення і у багатьох випадках приводить до помилкового застосування досвіду, відповідно, до неправильних чи низькоякісних порад.

2. Велика база даних може привести до зниження продуктивності системи.

3. Важко визначити хороший критерій для індексації та порівняння випадків. Словники пошуку й алгоритми визначення подоби необхідно ретельно налаштовувати вручну. Це може нейтралізувати багато переваг, що властиві міркуванням на основі досвіду.

Міркування на основі моделей. Переваги міркувань на основі моделей.

1. Можливість використання у вирішенні завдань функціональні та структурні знання про предметну галузь. Це збільшує ефективність механізму міркувань під час розв'язування різноманітних завдань, включаючи ті, які не були передбачені в розробці системи. 
2. Механізми міркувань на основі моделей, зазвичай, дуже ефективні. Вони $є$ потужним i гнучким засобом розв'язання завдань, оскільки, як i люди, часто повертаються до вихідних даних у разі зіткнення з новою проблемою.

3. Деякі знання можна використовувати в різних завданнях. Системи міркувань на основі моделей, зазвичай, базуються на теоретичних наукових знаннях. Оскільки наука, зазвичай, оперує загальними теоріями, таке узагальнення часто розширює можливості механізму міркувань на основі моделей.

4. Зазвичай, системи міркувань, заснованих на моделях, забезпечують причинні пояснення. Отже, користувачам можна передати більш глибоке розуміння причин несправності, яке може відіграти важливу навчаючу роль.

Недоліки міркувань на основі моделей такі.

1. Відсутність експериментального (описового) знання предметної галузі. Евристичні методи, що використовуються в міркуваннях на основі правил, відбивають важливий клас експертних оцінок.

2. Необхідність точної моделі предметної галузі. Знання з багатьох галузей мають наукову основу, яку можна використовувати в міркуваннях на основі моделей. Проте у багатьох сферах, наприклад у деяких медичних напрямах, більшості проблем проектування чи фінансових додатках, добре визначена наукова теорія відсутня. У таких випадках підходи, що засновані на моделях, не можуть бути використані.

3. Висока складність. Міркування, що засновані на моделях, зазвичай, проводяться на деталізованому рівні, що приводить до значних ускладнень. Саме 3 тієї причини експерти в першу чергу розробляють евристики.

4. Виняткові ситуації. Незвичайні обставини, наприклад, замикання чи взаємодія багатьох неполадок електронних компонентів, можуть змінити функціональність системи та, що її важко буде передбачити.

Гібридні системи. Важливою сферою досліджень є комбінація різноманітних моделей міркувань. У гібридній архітектурі, що об’єднує декілька парадигм, ефективність одного підходу може компенсувати слабкі сторони іншого. Комбінуючи різноманітні підходи, можна обійти недоліки, що властиві кожному з них окремо.

Наприклад, поєднання міркувань на основі правил і досвіду може забезпечити такі переваги. 
1. Перегляд відомих випадків до початку міркувань на основі правил дозволяє знизити затрати на пошук.

2. Приклади та виключення можна зберігати в базі даних ситуацій.

3. Результати пошуку можна зберігати для майбутнього використання. Водночас механізм міркувань дозволить уникнути витрат на повторний пошук.

Комбінація міркувань на основі правил і моделей відкриває такі можливості.

1. Пояснення доповнюються функціональними знаннями. Це може бути корисно в навчальних системах.

2. Підвищується стійкість системи за відмов. За відсутності евристичних правил, що використовуються в даному випадку, механізм міркувань може звернутись до міркувань від вихідних принципів.

3. Пошук на основі моделі доповнюється евристичним пошуком. Це може допомогти в складних міркуваннях, що засновані на моделі, і забезпечує можливість вибору.

Комбінація міркувань на основі моделей і досвіду дає наступні переваги.

1. Більш розумніше пояснення ситуацій.

2. Перевірка аналогічних випадків до початку більш екстенсивного пошуку засобами міркувань на основі моделей.

3. Забезпечення запису прикладів i виключень в базу даних випадків, які можуть бути використані для управління виведенням на основі моделі.

4. Запис результатів виведення на основі моделей для майбутнього використання.

Гібридні методи заслуговують уваги як дослідників, так і розробників додатків. Проте побудова таких систем вимагає розв’язання низки проблем. Необхідно визначити метод міркування для даної ситуації, момент зміни методу міркування, вияснити різницю між методами міркування, розробити представлення, що забезпечує спільне використання знань.

Висновки. Отже, поняття, якими оперують в різних галузях аналізу інформації і знань, виявляються насправді занадто складними та витонченими для того, щоб можна було скористатися традиційною логікою, у якій центральна роль відведена тільки точним, добре визначеним кількісним міркуванням. Теорія Л. Заде - чудовий метод обробки нечіткості або невизначеності; вона поза сумнівом сприяла не лише 
прояву описаної ситуації, але також зробила значний вплив на орієнтацію науковотехнічних досліджень. Для більшості методів обробки невизначеності, неясності і неточності в ускладнених умовах розв’язання проблем, зокрема в процесі дослідження педагогічного явища, виникає необхідність залучати методи теорії штучного інтелекту, а саме експертні системи, що збагачують і доповнюють теорію Л. Заде; особливо корисно використати ті можливості, які надаються найпопулярнішим напрямкам практичної реалізації штучного інтелекту інтелектуальним технологіям управління прийняття рішень: теорією нечітких множин та теорією нейронних мереж.

Використання нечітких даних пов'язане із системами, де неможливо отримати точну інформацію або має місце певна неясність, що пов’язана 3 неповною визначеністю мети, обмежень, критеріїв. Саме така ситуація склалася з отриманням даних у дослідженні педагогічних явищ та їх трактуванні. Нечіткі дані представляються у вигляді функцій належності. Прийняття рішень на основі нечіткої інформації передбачає залучення експертів. Їх досвід застосовується в процесі побудови систем, заснованих на нечіткій логіці $[1,6]$.

Як перспективні напрями подальшої нашої роботи вбачаємо практичну реалізацію експертних систем на основі нечітких баз знань в галузі досліджень педагогічних явищ та процесів. Зокрема, розробка експертної системи прогнозування змісту освіти за методикою, що запропоновано Б. С. Гершунським [2] та частково описаною нами [9] з позицій невизначеності та нечіткості.

\section{Список використаних джерел}

1. Борисов А. Н. Принятие решений на основе нечетких моделей: Примеры использования / А. Н. Борисов, О. А. Крумберг, И. П. Федоров. - Рига : Зинатне, 1990. - 184 c.

2. Гершунский Б. С. Прогнозирование содержания обучения в техникумах : учеб.-метод. пособ. / Б. С. Гершунский. - М. : Высш. школа, 1980. — 144 с.

3. Заде Л. Основы нового подхода к анализу сложных систем и процессов принятия решения / Лотфи А. Заде. // Математика сегодня (Сборник статей. Пер. с англ.). — М. : «Знание», 1974. - 64 с.

4. Заде Л. Понятие лингвистической переменной и его применение к принятию приближенных решений / Лотфи Заде. - М. : Мир, 1976. - 166 с. 
5. Люгер, Джордж, Ф. Искусственный интеллект. Стратегии и методы решения сложных проблем / Джордж Ф. Люгер. - 4-е изд. / пер. с англ. - М. : Издательский дом «Вильямс», 2003. - 864 с.

6. Мандель А. С. Метод аналогов в прогнозировании коротких временных рядов: экспертно-статистический подход / А. С. Мандель // Автоматика и телемеханика. - 2004. - № 4. - С. 143-152.

7. Михеев В. И. Моделирование и методы теории измерений в педагогике / В. И. Михеев. - Изд. 4-е, доп. - М. : КРАСАНД, 2010. - 224 с.

8. Танака К. Итоги рассмотрения факторов неопределенности и неясности в инженерном искусстве / К. Танака // Нечеткие множества и теория возможностей. Последние достижения : материалы науч. конф. / [пер. с англ. ; под ред. Р. Р. Ягера]. — М. : Радио и связь, 1986. - 408 с.

9. Цідило I. M. Застосування апарату нечіткої логіки для оцінки репрезентативності експерта / I. М. Цідило // Наукові записки ТНПУ. Серія: Педагогіка. - 2011. - № 4. - С. 171-177.

10. Zadeh, L. A. Fuzzy sets / L. A. Zadeh. - Inf. \& Control, 1965. — № 8. - P. $338-353$.

11.Zadeh L. A. A fuzzy-set-theoretic interpretation of linguistic hetges / L. A. Zadeh. J. Gybern, 1972. — № 2. — P. 4-34.

\section{НЕЧЕТКОСТЬ И НЕОПРЕДЕЛЕННОСТЬ: ОПИСАНИЕ, ИЗМЕРЕНИЕ И СПОСОБЫ РЕШЕНИЯ В МОДЕЛИРОВАНИИ ПЕДАГОГИЧЕСКИХ ЯВЛЕНИЙ}

Цидыло Иван Николаевич, кандидат педагогических наук, доцент кафедры компьютерных технологий, докторант Тернопольского национального педагогического университета имени Владимира Гнатюка, г. Тернополь, e-mail: tsidylo@ukr.net.

\section{Аннотация}

Рассматривается проблема представления знаний в исследовании педагогических явлений. Приведенные схемы представления неясности или неопределенности, приведенная классификация их основных свойств. Отмечено, что для некоторых классов подход, ориентированный на теории нечетких множеств и 
искусственном интеллекте. Что касается задания фактического измерения разнообразных характеристик педагогического явления, предложено применения экспертных систем, построенных на нечеткой базе знаний предметной области. Подведены итоги о преимуществах и недостатках рассмотренных технологий экспертных систем разработанных на основе: правил, моделей, опыта и гибридных систем.

Ключевые слова: неопределенность, нечеткость, случайность, неточность, искусственный интеллект, экспертные системы.

\section{FUZZINESS AND VAGUENESS: DESCRIPTION, MEASURING AND METHODS OF DECISION IN THE DESIGNING OF PEDAGOGICAL PHENOMENA}

Ivan M. Tsidylo, PhD (pedagogical sciences), associate professor of the Department of computer technologies, candidate for a doctor's degree of Ternopil National Pedagogical University named after Volodymyr Hnatyuk, Ternopil, e-mail: tsidylo@ukr.net.

\section{Resume}

The problem of representation of knowledge is examined in research of the pedagogical phenomena. The schemes of fuzziness and vagueness are represented in the article. It is mentioned, that for some classes the approach oriented to the theory of fuzzy sets and artificial intelligence. According to the task of actual measuring of various parts of the pedagogical phenomenon, it was suggested to use the applications of consulting models, which are built on the unclear base of knowledge of subject domain. It was summed up the advantages and disadvantages of the considered technologies of consulting models that is worked out on basis: rules, models, experiences and hybrid systems.

Keywords: vagueness, fuzziness, chance, inaccuracy, artificial intelligence, consulting models. 